\title{
INEQUITIES IN DISTRICTING FOR CONGRESS: BAKER v. CARR AND COLEGROVE Y. GREEN
}

\author{
GHARLES L, BLAGK†
}

THE opinion announcing the judgment in Colegrove v. Green ${ }^{2}$ has sometimes been treated with a deference insufficiently shaded by recognition that the circumstances under which it was uttered deprived it of authority. This would not matter much if the opinion satisfactorily dealt with the narrower and wider issues in Colegrove. With respect, it is submitted that it did not. ${ }^{2}$

The three Justices ${ }^{3}$ who joined it found the petitioners' claim for correction of congressional districting inequities "political," and hence "not meet for judicial determination." The first reason given was that the "basis for the suit is not a private wrong, but a wrong suffered by Illinois as a polity." In fact, the complaint in Colegrove (whether with or without merit, whether tendering or not tendering a "justiciable" issue) was of dilution of the plaintiffs' votes, of their own under-representation in Congress, as compared with the inhabitants of less populous districts. The contrast set up in the quoted statement was unreal; the basis for the suit was a wrong suffered by individuals (numerous, to be sure, but what of that?) in consequence of certain public arrangements in Illinois.

The rest of the opinion (insofar as it touches "justiciability") consists in suggestions of improprieties and dire effects. "It is hostile to a democratic system to involve the judiciary in the politics of the people" - yet, as de Toqueville first classically observed, in a saying too often quoted to quote again, such involvement is a settled and regular weight in our governmental balance; the qualification of voting rights as "political," and hence as unprotectible by courts, is (in a voice equally classic) "little more than a play upon words." "[D]ue regard for the effective working of our Government" and "for the Constitution as a viable system"' are said to preclude judicial action. The words "effective" and "viable" predict untoward consequences if the Court were to intervene; but what basis was there for the forecast that our Government would work

† Henry R. Luce Professor of Jurisprudence, Yale Law School.

1. 328 U.S. 549 (1946).

2. See Note, Constitutional Right to Congressional Districts of Equal Population,

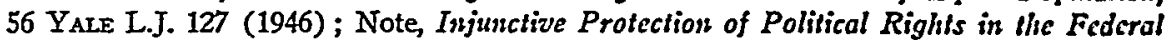
Courts, 62 Harv. L. Rev. 659, 662-65 (1949).

3. Justices Frankfurter, Reed and Burton.

4. 328 U.S. at 552.

5. Ibid. See Taylor, Legal Action to Enjoin Legislative Malapportionment: The Political Question Doctrine, 34 So. CaL. L. REv. 179, 185 (1961).

6. 328 U.S. at 553-54.

7. Nixon v. Herndon, 273 U.S. 536, 540 (1927) (Mr. Justice Holmes).

8. 328 U.S. at 552. (Italics supplied.)

9. Id. at 554. (Italics supplied.) 
less effectively, or that the Constitution would become unviable, if the Court gave its aid to the Colegrove petitioners? We are told, thirdly, that redress of the Colegrove wrong should be sought in the electoral process ${ }^{10}$-but is this a practicable suggestion, when the wrong complained of is the corruption of the electoral process ? $^{11}$

The judgment-announcing opinion in Colegrove asserts the impropriety of judicial intervention, but does not convincingly show wherein that impropriety consists. It predicts pernicious consequences on such intervention, but does not make these predictions plausible-much less show that they are worse than the prevailing situation. The opinion can satisfy only if one starts with the postulate that judicial wisdom, in constitutional litigation, always consists in judicial self-restraint, and that the reasons proferred for such restraint are, like non-traversable allegations at common law, always to pass for wellfounded, if stated in the set terms of art.

Colegrove v. Green, then, has long needed to be put accurately in its place. This is done by the opinion of the Court in Baker v. Carr. ${ }^{12}$ The opinion announcing the Colegrove judgment stated the views, on the question of justiciability, of a minority of the sitting Court. ${ }^{13} \mathrm{~A}$ majority thought the tendered issue justiciable, either on reason or on authority. ${ }^{14}$ That is the short truth about Colegrove v. Green, and it is good to see it so shortly and plainly stated in the opinion of a Court majority. ${ }^{15}$ The complex discussion can now proceed with Colegrove out of the way.

It does not thereby lose its complexity. The complication that comes first into at least one mind is that Colegrove and Baker are, in a federal system, very different cases indeed. Colegrove concerned the application of federal constitutional requirements to elections to the federal legislature, while Balicr points at the structure of state governments. Considerations of federalism must surely be a part of constitutional equity; it is the thesis of this brief comment that the Court, having duly chronicled the imperial clothing of Colegrove, will best show its wisdom, as a court of equity under the Constitution, in giving weight to certain factors which seem to make thoroughgoing judicial scrutiny of congressional districting schemes even more suitable than an analogous searching of the constituency-patterns of state legislatures.

The first consideration is that of remedy. Here it seems that there is a far stronger case for vigorous judicial activism in the congressional than there is

10. Id. at 556 .

11. "The fallacy of withdrawing judicial protection of the right to vote lies in the selfperpetuating nature of disenfranchisement." Note, Injunctive Protection of Political Rights in the Federal Courts, 62 HARv. L. Rev. 659, 668 (1949). See also Taylor, sutpra note 5, at $187-88$.

12. 369 U.S. 186 (1962).

13. 328 U.S. at 550-56 (opinion by Mr. Justice Frankfurter joined by Justices Reed and Burton).

14. See $i d$. at 564-66 (opinion by Mr. Justice Rutledge, who concurred in the Court's result) and id. at 566-74 (dissenting opinion by Mr. Justice Black joined by Justices Dourclas and Murphy).

15. 369 U.S. at $232-33$. 
in the state-legislative situation-that the remedial possibilities, multifarious and clouded in the second, are clear and simple in the first.

It is not here asserted that beneficial remedies never can be framed in the state-legislature cases. First of all, state law itself-the formal expression of the state's will-may (as the Tennessee case itself will probably illustrate when the decree is made up) furnish a guide. The concept of "equal protection of the laws" takes on a freshly literal meaning here; to force a state to apply its existent laws equally seems close to the root meaning of that phrase, and, where those laws themselves furnish a sufficiently concrete guide to the shaping of a decree, there is no reason for a federal court's not using them, in coaction with the equal protection clause, as its basis for the molding of relief.

Other special factors, assessable state by state, may make the administration of relief less hopeless than a glance might lead the most pessimistic judge to think. ${ }^{16}$ It is a backhanded kind of comity, moreover, which would indulge, as an in limine objection to judicial cognizance, the assumption that the states will defy the judicial mandate. Nor has the anticipation-even the certaintyof some such defiance always proven an obstacle to the Court's doing what it can, and thereby accomplishing much. The rule of Strauder $v$. West Virginia ${ }^{17}$ has for eighty years been openly flouted or circumvented through thousands of square miles of territory, to cite only one instance.

Still, the difficulty of finding a bearable ultima ratio must be a factor in approaching the state-legislative cases. First, the ordering of an election-atlarge, of an entire legislature or one of its houses, is not satisfactory. The result would be something, but it could hardly be called a state legislature. In many if not all the states, it would have no state constitutional standing, for it would broadly fail to answer the description of the legislature in the state constitution. In this event, there would be either no legislature de jurc, or a legislature legitimized solely by federal court decree-a possible but surely not a desirable condition.

Second, to treat all laws passed by the legislature as void, until proper redistricting occurs, is an anarchic remedy that will commend itself to nobody. ${ }^{18}$

Third, Virginia $v$. West Virginia ${ }^{10}$ sufficiently documents the hesitancy a federal court must feel in directing coercive process at the legislature itself.

Fourth, for the court to redistrict on its own (using a Master if needful) is subject to the objection that, whatever the requirements of the fourteenth amendment may ultimately be made out to be, it is clear that these can be met, in the case of any state, by any one of an infinity of different plans. For

16. "Equity" (though this could not be guessed from some constitutional opinions) is not merely a set of rules conducive to judicial abstention; its deeper tradition is the molding of adaptable, creative remedies.

17. 100 U.S. 303 (1880). This case laid down the proposition that the equal protection clause of the fourteenth amendment forbids racial discrimination in the selection of juries for trials in state courts.

18. See Luther v. Borden, 48 U.S. (7 How.) 1, 38-39, 43 (1849) ; cf. Baker v. Carr, 369 U.S. 186, 219 (1962).

19. 246 U.S. 565 (1918). 
example, Legislative District $\mathrm{X}$ may be given the right number of inhabitants by bringing within it either Town $\mathrm{A}$ or Town $\mathrm{B}$. If Town $\mathrm{A}$ is strongly Republican and Town $B$ is strongly Democratic, and if District $X$ is now closely divided, the choice will be worth fighting over. No court has any basis-in law or in judicial discretion-for making this choice. Yet the affirmative devising of a districting plan is a very long series of such choices.

It may be anticipated, then, that, where the states show maximum recalcitrance on reapportionment for their own legislatures, the courts are going to have difficulty in finding suitable remedies.

By contrast, the judicial remedy in congressional cases is clear, simple, and moderate-the ordering of election-at-large of the offending state's congressional delegation, pending proper redistricting. ${ }^{20}$ Congress is still Congress, formed according to the Constitution and able to function normally, no matter how many Congressmen-at-large come from any given state. ${ }^{21}$ The state itself is fully represented. The value lost-intra-state local representation-is not of the first order of importance, and is easily to be regained by the affected state, at the bargain price of redistricting properly. Only subordinate officials need be placed under injunction; the command of the injunction can be simple. All the purely political judgments inherent in actual redistricting are automatically made by the state legislature, when that body gets around to it. No plank has been walked, no Rubicon crossed. Yet the applied pressure, though moderate, is pretty sure to work, because the recalcitrant interest, in respect to redistricting, is ex hypothesi a minority interest, which will lose ground maximally as long as elections are at large in the whole state, and which (again ex hypothesi) controls the state legislature and so can redistrict when it will.

On the score of remedy, then, the congressional case (such as Colegrove v. Green) is more promising than the state-legislative case. Closely connected with the matter of remedy is that of substantive standards-and as to these, it is submitted, the congressional case is again on the solider ground.

20. Smiley v. Holm, 285 U.S. 355, 374-75 (1932). See Mr. Justice Black's disscnt in Colegrove v. Green, 328 U.S. 549, 573-74 (1946); Taylor, supra note 5, at 187; Lewis, Legislative Apportionment ant the Federal Courts, 71 HARv. L. Rev. 1057, 1087-90 (1958).

21. There was no federal requirement of districting until 1842. See Colegrove v. Green, supra note 20 , at 555 . Even after that some states have elected representatives at large. See id. at 557-58 (app. 1). It seems, moreover, that the federal requirement for election by districts must be taken to have lapsed between 1929 and 1941. Wood v. Broom, 287 U.S. 1 (1932), held that Act of August 8, 1911, ch. 5, § 3, 37 Stat. 14, which embodied the districting requirement, expired on the passage of Act of June 18, 1929, ch. 28, § 22, 46 Stat. 26. The latter statute contained no districting requirement. Nor, curiously, does the law now in force categorically require districting, though it assumes it. Act of Nov. 15, 1941, ch. 470, 55 Stat. 761, 2 U.S.C. \& $2 \mathrm{a}$ (c) (1958). Various contingencies are provided for, on its happening that a state has not been "redistricted in the manner provided by the law thereof after any reapportionment ...." Two of these entail the continuance of at least a partial election-at-large. Two entail the institution of new elections-at-large-in one case partial and in one total. The law nowhere commands the state to district, and seems to concede the propriety of election-at-large of at least some part of a state's delegation. Congress is evidently not horrified by the idea of elections-at-large. 
The state patterns must respond to section one of the fourteenth amendment alone, while the federal elections are ruled also by article $I$, and by the second section of the fourteenth amendment. The last-named provision breathes the spirit of "apportionment"; it is hard not to see in this, and in the article I requirement of election by "the People," a federal plan for the House of Representatives constituency. Without exploring close questions, would it be consonant with this federal plan, entirely aside from fourteenth amendment "equal protection," for Georgia to deprive the inhabitants of Atlanta of any representation in the Georgia delegation to Congress? If it would not, then there is an article I substantive law of representation in Congress; $; 2$ the questions are of degree only, and they are federal questions. ${ }^{23}$

Whatever standards may emerge, state or federal, it seems they cannot be precise or absolute; "reasonable" departures from equality will be permitted. The law of the subject will most likely be a law of the permissibility and impermissibility of such departures. If this is so, the federal courts and federal constitutional law are vastly more apt to evaluating the factors justifying departures from equality with respect to the federal legislature than they are to evaluating the analogous factors with respect to the states.

Geographical as opposed to popular representation will be the main pattern continually requiring evaluation. As long as the United States Senate sits it would seem hard for any court to hold that representation by political units, without regard to population, is absolutely forbidden as to both houses of a state legislature. Nor is it easy, once granted the propriety of sectional representation, to hold the states rigidly to a pattern exactly analogous to the federal one, with geography a permissible criterion in only one house. As to Congress, on the other hand, it is at least tenable to conclude that representation of the relevant constituent political units, without regard to population base, is wholly taken care of in the Senate, and that the House, which is to be elected by the people pro rata, is to represent the popular principle fully and effectively. Surely it would not be strange to find that one part of one branch of a democratic government lives under that requirement.

All in all, the propriety of methods of electing state legislatures is a state matter, subject only to overriding federal requirements. The propricty of modes of election to Congress is throughout and by its four corners a federal matter, governed by the whole federal plan in all its implications and with no extrinsic considerations to weigh. The federal courts can and ought to move with more confidence and competence in the latter than in the former field. And the guess may be ventured that the people of the states will more readily accept such

22. See Mr. Justice Black's dissent in Colegrove v. Green, 328 U.S. 549, 570-71 (1946). See also Lewis, supra note 20, at 1071-77.

23. That they are questions of degree hardly makes them unsuitable for judicial resolution; it would be disappointing to hear, from the lips of those who have made so much of insisting that all constitutional rights are subject to intricate "balancing," that the necessity for such supra-textual balancing makes a question "non-justiciable" See Lewis, supra note 20 , at $1083-86$. 
intervention, where it concerns a matter of very evident primary national interest. The federal courts, policing elections to the federal Congress, cannot be seen as interfering with the structure of another government than the one of their own commissioning. Most people are now aware that constitutional law, like all law, is not merely a set of static principles but a process, even a quest; surely federal constitutional law may quest more reliantly after wholly federal standards, than after those entangled with state internal structure.

Up to this point, every consideration leads to looking on the Colegrove situation as one to which judicial scrutiny, for federal constitutionality, is more apt than it is to the Baker situation. One major problem remains-that of deference to Congress itself, as a coordinate branch, as legislator in regard to "Times, Places and Manner" of its members' elections ${ }^{24}$ and as judge (Fouse by House) of their "Elections, Returns and Qualifications."25

The first thing to get out of the way here is Wood v. Broom.20 That case held that Congress, in passing the 1929 apportionment law, ${ }^{27}$ without carrying over the 1911 (and long traditional) requirements of compactness, contigutity, and approximate population equality in congressional districts, ${ }^{28}$ had effected this omission by design, and so left no statutory standard to which the voter could appeal. The danger in the case is that it may be taken to have held that Congress not only designed to omit the standards of 1911, but, in so doing, expressed a positive conviction actually hostile to the standard of approximate equality. ${ }^{28}$ If this were true, the problem of judicial deference to Congress would be at a maximum. But the legislative history cited by the Court in Wood v. Broom shows that it is not true. ${ }^{30}$

When the 1929 reapportionment bill came on for debate in the Committce of the Whole House, Congressman Lozier of Missouri attacked several of its sections, including the one which would have provided for compactness, contiguity, and approximate equality, as plainly unconstitutional on the ground that "... Congress has no power to determine in what manner [sic, notwithstanding article I, section 4] the several States exercise their sovereign rights in selecting their Representatives in Congress ...."31 This attack was a broadside against three sections of the bill; no attempt was made to make it chime either with past practice or with applicable constitutional language. Congressman Graham of Pennsylvania, on the other hand, remarked, "I was wondering whether the third and fourth paragraphs were really necessary, because the

24. U.S. Const. art. I, § 4.

25. U.S. Const. art. I, $\S 5$.

26. 287 U.S. 1 (1932).

27. Act of June 18,1929 , ch. $28, \S 22,46$ Stat. 26.

28. Act of Aug. 8,1911 , ch. 5, $\$ 3,37$ Stat. 14.

29. Such a broader interpretation of the Broom case was approached in Daly v. Madison County, 378 I1l. 357, 363-64, 38 N.E.2d 160, 164 (1941).

30. For this short comment, the writer has consulted only that legislative history which was cited by the Court.

31. 70 Cong. Rec. 1496 (1929). 
law itself would take care of that."32 Congressman Dickinson of Iowa declared on the policy of the matter: "Section 3 [embodying the requirement we are here interested in] ought not to be in here, because the States ought to have their own way of making up their apportionments when they know the number of Congressmen they are going to have."33 The next time the bill came up, Congressman Fenn, its manager, moved to strike section 3, giving no reasons, and the amendment "was agreed to," no record vote or count appearing. ${ }^{33}$

$\mathrm{Up}_{\mathrm{p}}$ to this point, all we have is the elimination of a provision, by a vote of unknown proportions, in a single House, on a mixture, in unknown proportions, of these grounds: (1) the entirely untenable ground that the eliminated requirement was unconstitutional-that the Congress to which the Court might "defer" actually had no power over the matter; (2) the policy ground that Congress ought to abstain from dealing with the matter (which is not the same thing as a congressional expression hostile to the application of any constitutional requirement) ; (3) the ground that, since the requirements were a part of the standing law, it were otiose to include them..$^{35}$ To convert such an expression on the part of one House into a positive Congressional declaration that the states shall be free to set up discriminations, however gross and irrational, is to tempt the pen of a latterday Dickens-or Kafka.

There is more. The Court in Wood v. Broom cites further legislative history concerning an attempted amendment, by Congressman Reed of New York, to the census and apportionment bill that finally passed in the 71st Congress. The bill (S. 312) contained no "equality" requirement. ${ }^{30}$ In the Committee of the Whole House, Mr. Reed offered the following amendment:

Nothing in this act contained shall be construed to prevent the legislature of any State (subject, however, to the initiative and referendum law in any State wherein such a law exists), at any time after the approval of this act, in order to secure contiguous and compact territory and equalization of population in accordance with the rules enumerated in section 3 of the apportionment act, approved August 8,1911, by concurrent resolution, redistricting the State for the purpose of electing Representatives to Congress, and upon each and every such redistricting the Representatives to Congress shall in any such State be elected from the new districts so formed. $^{37}$

It will be seen that this amendment was not addressed directly to restoring the omitted requirements; it rather assumed their existence in the background,

32. Ibid. Mr. Graham's actual position is not clear; there immediately follows the statement (true but without vector) that "Under the Constitution the power rests with the States to regulate except so far as Congress may enact legislation. . . ." Mir. Lozier, delivering his constitutional opinion, seems to say that Mr. Graham agrees with him. It is certain, however, that some members thought the 1911 requirements remained (see test at note 39 infra), and Graham's statement, unless entirely thoughtless, seems to place him with these.

33. 70 Cong. REC. 1499 (1929).

34. 70 Cong. Rec. 1604 (1929).

35. This is subject to the qualifications suggested in note 32 sipra.

36. See Wood v. Broom, 287 U.S. 1, 7-8 (1932).

37. 71 CoNG. REc. 2280 (1929). 
and empowered the state legislatures to give them effect. The crux of the amendment, as the debate shows, was the elimination of the requirement of gubernatorial approval to districting plans; the words "concurrent resolution" were the heart of the matter. Mr. Reed was afraid that all forty-odd New York Congressmen would be elected at large, by New York City Democrats, if there should be a districting deadlock between the Legislature and the Governor.

A point of order to this amendment was sustained, on the ground that nothing in the pending bill dealt with state redistricting and that the amendment was therefore not germane. Reed offered the same amendment again at a later stage, saying (among other things) that he wanted to make sure Sections 3 and 4 of the 1911 Act were not repealed. Congressman Crowther of New York asked, "Does the gentleman ... think that sections 3 and 4 in the 1911 act are really inconsistent with the present act?" The ensuing colloquy makes plain that neither Reed nor Crowther (nor, so far as is shown, anybody else) was willing to say he thought so. Mr. Reed's amendment (as far as this point goes) was offered out of abundant caution, against a "possible construction."

A point of order was again taken, on grounds of non-germaneness. Congressman French of Idaho spoke against it; he thought that the 1911 sections were not being repealed, and that the Reed amendment therefore zuas germane. ${ }^{30}$ The Chairman (Congressman Chindblom of Illinois) sustained the point of order, on a reverse theory. His statement is not entirely free from ambiguity, but his reasoning was, in part, that the 1911 sections were not being repealed, and that the pending bill therefore did not itself deal with state redistricting at all, so that the amendment was not germane to the bill's subjectmatter.40

This history seems to support the conclusion of a commentator on Wood v. Broom : "While not definitely expressed, it is apparent that Congress did not realize that the 1930 apportionment would cause the Act of 1911 to expire by its own terms." 41 Correspondingly, some doubt is cast on the correctness of

38. 71 CoNG. REc. 2444 (1929).

39. Ibid.

40. 71 CoNG. Rec. 2444-45 (1929). At the very least, the Chairman clearly thought that the pending bill did not contain any affirmative expression at all on the subject of district equality.

41. 81 U. PA. L. Rev. 343, 344 n.12 (1933). A very strict reading of the whole of scction 3 of the 1911 act might have saved its requirements. The Wood v. Broom reasoning is that the section "expressly applied" only to "this apportionment," 287 U.S. at 6-i.c., the one following the 1910 census. In: fact, in its own words, it expressly applied to "cach State entitled under this apportionment to more than one Representative," and, as to such states, to their Representatives "to the Sixty-third and each subsequent Congress . . . ." Act of Aug. 8, 1911, ch. 5, § 3, 37 Stat. 14 (italics supplied). A calculating machinc, fed these phrases, would have to punch out that the section remained in force indefinitely, except as to Delaware, Nevada, Wyoming, Arizona, and New Mexico. If this literal reading were opposed to a broadly equitable one, it joyfully could be rejected. But if the Wood $v$. Broont result (itself based on a highly literal reading), had no equity and no real congressional intent behind it, the case might have been one where the proper remedy for literalism was more literalism. 
Wood v. Broom. But we need not pursue that doubt. The important thing now is that nothing in the legislative history on which that decision was grounded gives the slightest warrant for the conclusion that Congress, or its either House, expressed an affirmative wish that congressional districts be as inequitable as the states want to make them. ${ }^{42}$ It need not be considered what deference the Court ought to pay to such a graceless declaration, if it ever were expressly and clearly made, in regular affirmative law passed by both Houses and signed by the President. 33

The question then comes down to this: Do the constitutional grants of power to Congress over congressional elections support an inference that the judiciary is excluded from dealing with inequitable districting for the same elections? Certainly this inference could not rest on any wide major premise; courts are not generally forbidden to deal with matters with which Congress also may deal, as many decisions under the fourteenth and fifteenth amendments show.

It is best to leave the making of a case for such an inference to those to whom it seems plausible. To the present writer, it does not seem plausible. The "Elections, Returns and Qualifications" power," residing in either House, seems addressed to other problems altogether, and contemplates inquiry and judgment after the fact, rather than antecedent dealings with discriminatory patterns. ${ }^{45}$ The "Times, Places and Manner" power, ${ }^{10}$ though wide enough (certainly in connection with section 5 of the fourteenth amendment) to empower Congress to act on inequitable districting, need not import the exclusion of a concurrent judicial competency.

The race-discrimination cases seem almost to put the question to rest. Congress has ample power to deal with state-imposed racial discriminations in elections and preceding primaries. Yet the courts have felt no reluctance to deal with the same subject. ${ }^{47}$

42. See note 29 supra and accompanying text.

43. The nearest thing to this is the Act of Nov. 15, 1941, 55 Stat. 761, 2 U.S.C. $\& 2 a$ (1958), discussed note 21 supra. This law does not speak at all to the propricty of nezv districts, but provides for the use of the old ones pending redistricting by the state (with necessary adjustments through elections-at-large). Even as to that command, the weight of attention seems clearly to rest on setting up a modus vivendi pending redistricting, and not on the permanent sanctification of rottem boroughs. That sanctification would operate erratically, for under the section's terms it could never avail a state whose delegation is decreased after any census, for such a state must either redistrict or elect all its Congressmen at large. As a whole, even where the section literally commands temporary use of the old districts, it seems fully warranted to subject it to the normal overriding principle that state action under it must meet federal constitutional standards. A congressional intent to exempt the state from these ought not to be read into a housekceping provision.

44. U.S. Const. art. I, \& 4.

45. This "remedy" is entirely unadapted to the evil. It would rarely, if ever, be possible to show who would have been elected if districting had been fair; absent this, the only choice would be to reject all Representatives elected from unfair districts and leave their constituents wholly unrepresented. See Comment, Methods for Guarantecing Equality in Congressional Districts, 43 ILI. I. REv. 180, 183 (1948).

46. U.S. CoNsr. art. I, $\S 5$.

47. See, e.g., Gomillion v. Lightfoot, 364 U.S. 339 (1960). 
: Practical remedial factors, then, make judicial dealing with congressional districting even more suitable than with state-legislature districting. Standards for congressional districting are federal in their affirmative reach and in their admission of qualifications; the development of federal constitutional criteria should therefore be freer in the congressional than in the state-legislature situntion. So far as appears, no general or particular inference arises, from the language of the Constitution, that judicial treatment of the congressional situation is unsuitable. It is therefore submitted that, in the congressional cases even more than in the state-legislative cases, the Court ought to be guided by the prudent courage of Mr. Justice Clark's words in Baker v. Carr, words that may reach further than the particular subject, to mark a turned corner in judicial philosophy:

As John Rutledge (later Chief Justice) said 175 years ago in the course of the Constitutional Convention, a chief function of the Court is to secture the national rights. Its decision today supports the proposition for which our forebears fought and many died, namely, that to be fully conformable to the principle of right, the form of government must be representative. That is the keystone upon which our government was founded and lacking which no republic can survive. It is well for this Court to practice self-restraint and discipline in constitutional adjudication, but never in its history have those principles received sanction where the national rights of so many have been so clearly infringed for so long a time. National respect for the courts is more enhanced through the forthright enforcement of those rights rather than by rendering them nugatory through the interposition of subterfuges. In my view the ultimate decision today is in the greatest tradition of this Court. ${ }^{48}$

48, 369 U.S. 186, 261-62 (1962) (footnotes omitted). 